
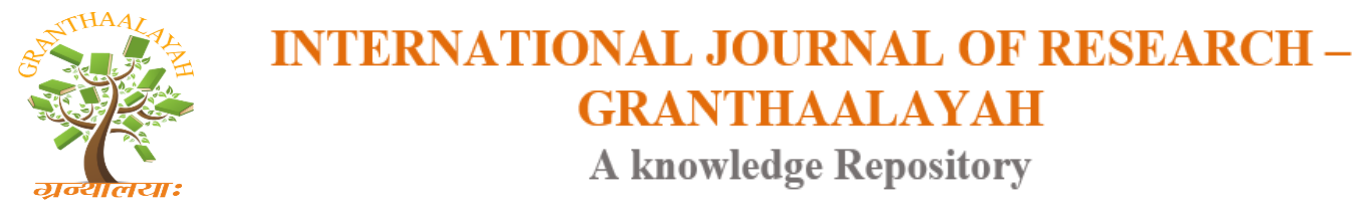

Science

\title{
PRELIMINARY STUDY OF MOLLUSCAN DIVERSITY IN PARIYAT RIVER, JABALPUR (M.P.)
}

\author{
Rita Bhandari ${ }^{1}$, Arjun Shukla ${ }^{* 2}$, Shivani Rai ${ }^{3}$ \\ ${ }^{1}$ Professor and Head, Department of Zoology, Govt. O.F.K. College, Jabalpur (M.P.), INDIA \\ ${ }^{* 2,3}$ Research Scholar, Department of Zoology, Govt. Model Science College, Jabalpur (M.P.),
} INDIA

DOI: https://doi.org/10.29121/granthaalayah.v4.i9.2016.2547

\section{ABSTRACT}

Mollusca diversity of Pariyat River was studied during June 2015 to April 2016. After construction of Dairies in the surroundings and bank of Pariyat River, a major part of running water is being converted in to sludge. Mollusca fauna is correlated with biological and various physico-chemical parameters that regulate abundance and distribution of different species. In present study, attempts have been made to collect, classify and identify Mollusca of Pariyat River in Panagar region. The survey indicated that 157 individuals from 13 families of Mollusca were found in this zone of the river. Out of 13 families of Mollusca 9 species are belonging to class Gastropoda and 3 species to class Bivalvia. The major Mollusca abundance was noticed viz. Pila sp. and Bellamya sp. Shannon's Diversity Index (H) was calculated from the recorded 157 individuals has value -1.024955387 which is inverse to Simpson's Index (C) has value 0.10462899. Diversity indices indicate a good ratio of species diversity in the study site. In future, habitat destruction, introduction of sludge and pollution lead to decline of species. An urgent need exists for studying the life history traits and demography of the most important threatened Mollusca, as lack of information on these aspects have significantly affected conservation efforts.

Keywords:

Diversity Indices, Pariyat River, Mollusca Richness, Dairies.

Cite This Article: Rita Bhandari, Arjun Shukla, and Shivani Rai, "PRELIMINARY STUDY OF MOLLUSCAN DIVERSITY IN PARIYAT RIVER, JABALPUR (M.P.)” International Journal of Research - Granthaalayah, Vol. 4, No. 9 (2016): 136-142.

\section{INTRODUCTION}

Molluscs are most ancient invertebrates on earth today. Mollusca constitute an important part of ecosystem and play a critical role in maintaining aquatic ecosystem by recycling the nutrients and serve as main food for many aquatic creatures. Hence, their existence is necessary to maintain food web and equilibrium in ecosystem (Subba Rao, 1989; Begum and Narayana, 
2006). Mollusca is an extraordinarily varied phylum with estimates of 80,000 to $1,00,000$ described species and total diversity may reach as high as 2,00,000. Molluscs are highly diversified group after Arthropods and also most successful of all animals. The largest molluscan classes i.e., Gastropoda and Bivalvia have successfully survived in all continents (fresh water) except Antarctica (Strong et al., 2008). Freshwater gastropods are found nearly all aquatic habitats including rivers, lakes, streams, swamps, underground aquifers and springs, as well as temporary ponds, drainage ditches and other ephemeral and seasonal waters. Most of the mollusca lived submerged throughout the life, and many are specialized for particular habitats such as aquatic vegetation, stones, rocks, wood and other solid surfaces or soft sediment to complete their life cycle. Some are amphibious and few are able to tolerate periods of time out of water such as species of Ampullariidae family while others are capable of prolonged periods of aestivation in soil during dry periods. Biodiversity loss is a worldwide threat due to intensive anthropogenic activities such as changes in land or water use and destruction of environmental resources. Pariyat River is originated from Kundam and further joined to Hiran River which drains water in river Narmada. Pariyat River has turned into dirty Nullah's in Panagar region, and even river Narmada is turning polluted by discharge of cow dung by offending bunch of dairy owners, who disregarded environmental concerns. Dairy effluents let out into water stream without treatment render water unfit for survival of aquatic fauna and human use. Humanneeds for a particular resource conflict with the conservation of that resource that leads to destruction of habitat. Natural populations of freshwater gastropods are severely affected by ecological constrains and fluctuation in the abiotic factors and their survival is depend upon physiological capacity to tolerate these stress and fluctuations (Kalyoncu, 2009). Gastropods usually play an important role in fresh water ecosystem by providing food for many animals and by grazing on vast amounts of algae and detritus (Agudo-Padron, 2011). Recent reports suggest that the tropics are losing biodiversity at an alarming rate (Sodhi, 2008). However, there is very little knowledge on the extent of loss in lesser known groups, especially the invertebrates. The paper highlighted diversity and abundance of Mollusca and the need for their conservation. The aim of this study is the assessment of the environment and detection of species diversity of fresh water Mollusca in Pariyat River at Panagar region, Jabalpur.

\section{MATERIAL AND METHOD}

The study site includes river Pariyat near Panagar in Jabalpur city. The studies carried out from June 2015 to April 2016 to calculate diversity indices of Mollusca. Mollusca was collected from surrounding area of Pariyat river in Panagar region and deeper Profundal zone by using Ekman grab and at shallow Profundal zone by using surber sampler following Wetzel (2001) in the river. All the samples were preserved in field with $5 \%$ formalin solution. Organisms were identified by using standard keys, such as Tonapi (1980), Adoni et al., (1985) and SubbaRao (1993). ShannonWeiner diversity index $(\mathrm{H})$ was calculated using Shannon-Weiner equation according to Mangurran (1988) and the dominance index that is Simpson index (C) was calculated according to Sklar (1985).

1) Calculation of Shannon's Species Diversity Index (H) (Shannon, 1948). $\mathrm{H}=-\sum(\mathrm{ni} / \mathrm{N}) \times \log (\mathrm{ni} / \mathrm{N}) \mathbf{O R}-\sum \mathrm{Pi} \times \log \mathrm{Pi}$ Where,

$\mathrm{H} \quad=\quad$ Shannon Index of Diversity. 
ni $=\quad$ Number of individual of each species.

$\mathrm{N}=$ Total number of individuals in the sample, (i.e., $\mathrm{N}=\sum$ ni).

$\mathrm{Pi} \quad=\quad$ Importance probability for each species, (i.e., $\mathrm{Pi}=\mathrm{ni} / \mathrm{N}$ )

2) Calculation of Simpson's Index of Dominance (C) (Simpson, 1949).

$\mathrm{C} \quad=\quad \sum(\mathrm{ni} / \mathrm{N})^{2} \mathbf{O R} \sum(\mathrm{Pi})^{2}$

Where,

$\mathrm{C}=\quad$ Number of individual of each species

ni $=$ Number of individual of each species.

$\mathrm{N}=$ Total number of individuals in the sample, (i.e., $\mathrm{N}=\sum$ ni).

$\mathrm{Pi}=$ Importance probability for each species, $(\mathrm{i} . e ., \mathrm{Pi}=\mathrm{ni} / \mathrm{N}$ )

\section{RESULT}

During the study, total 157 Molluscan individuals of 13 Genus, each belong to one family of class Gastropoda and Bivalvia have been recorded from the study site during six month intensive study tabulated in (Table 1).

Table 1: List of recorded species of Mollusca in Pariyat River Jabalpur Region.

\begin{tabular}{|c|c|c|c|c|}
\hline \multirow{2}{*}{$\begin{array}{l}\text { S. } \\
\text { No. }\end{array}$} & \multirow[b]{2}{*}{ Family } & \multirow[b]{2}{*}{ Name of The Species } & \multicolumn{2}{|c|}{ Site: Pariyat River, Panagar Jabalpur } \\
\hline & & & No. of Speciesseen & Status \\
\hline \multicolumn{5}{|c|}{ Class: Gastropoda (Univalve Shell) } \\
\hline & Pilidae & Pila sp. & 24 & Very Common \\
\hline & Viviparidae & Bellamya sp. & 22 & Very Common \\
\hline & Valvatidae & Valvatapiscinalis & 07 & Rare \\
\hline & Littorinidae & Cremnoconchus sp. & 08 & Rare \\
\hline & Ancylidae & Ferrissia sp. & 2 & Very Rare \\
\hline & Hydrobiidae & Potamopyrgus sp. & 17 & Common \\
\hline & Lymnaeidae & Lymnea sp. & 19 & Common \\
\hline & Planorbidae & Segmentia sp. & 11 & Not rare \\
\hline & Physiidae & Physellaacuta & 06 & Rare \\
\hline \multicolumn{5}{|c|}{ Class: Bivalvia (Two valved Shell) } \\
\hline & Unionidae & Lamellidens sp. & 07 & Rare \\
\hline & Amblemidae & Parreysia $s p$. & 17 & Common \\
\hline & Margaritiferidae & Margaritifera $s p$. & 16 & Common \\
\hline & Cultellidae & Tanysiphon sp. & 1 & Very Rare \\
\hline
\end{tabular}




\section{RELATIVE ABUNDANCE}

The relative abundance of 13 recorded species of Mollusca was figured out in (Graph 1). 15\% species Pila and Bellamya species were found to be very common belong to class Gastropoda, $31 \%$ species were common that are Potamopyrgus and Lymnea under Gastropoda and Perreysia and Margaritifera under Bivalvia, 31\% species were rare in which one species Lamellidens belongs to class Bivalvia, and Valvatapiscinalis, Cremnoconchus and Physellaacuta belongs to Gastrapoda, $8 \%$ species that is Segmentia was not rare and $15 \%$ species were very rare found to the study areas shown in (Graph 2). Dominance of Pila sp. was seen in the study site. These $31 \%$ species of Mollusca from the study area were designated rare and $15 \%$ species as very rare, suggesting the need for strict conservation. According to their relative abundance, the specimens found during the six month investigation were classified as follows: 20-25 under very common, 15-20 were categorized under common, 10-15 were categorized under not rare, and 5-10 were categorized under rare while below 5 were categorized under very rare species.

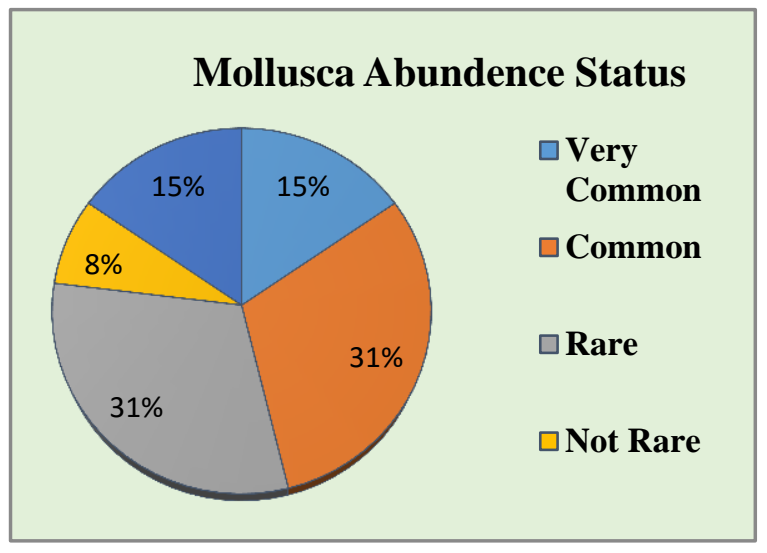

Graph 1: Abandence Status of Mollusca in Pariyat River at Panagar region, Jabalpur (M.P.)

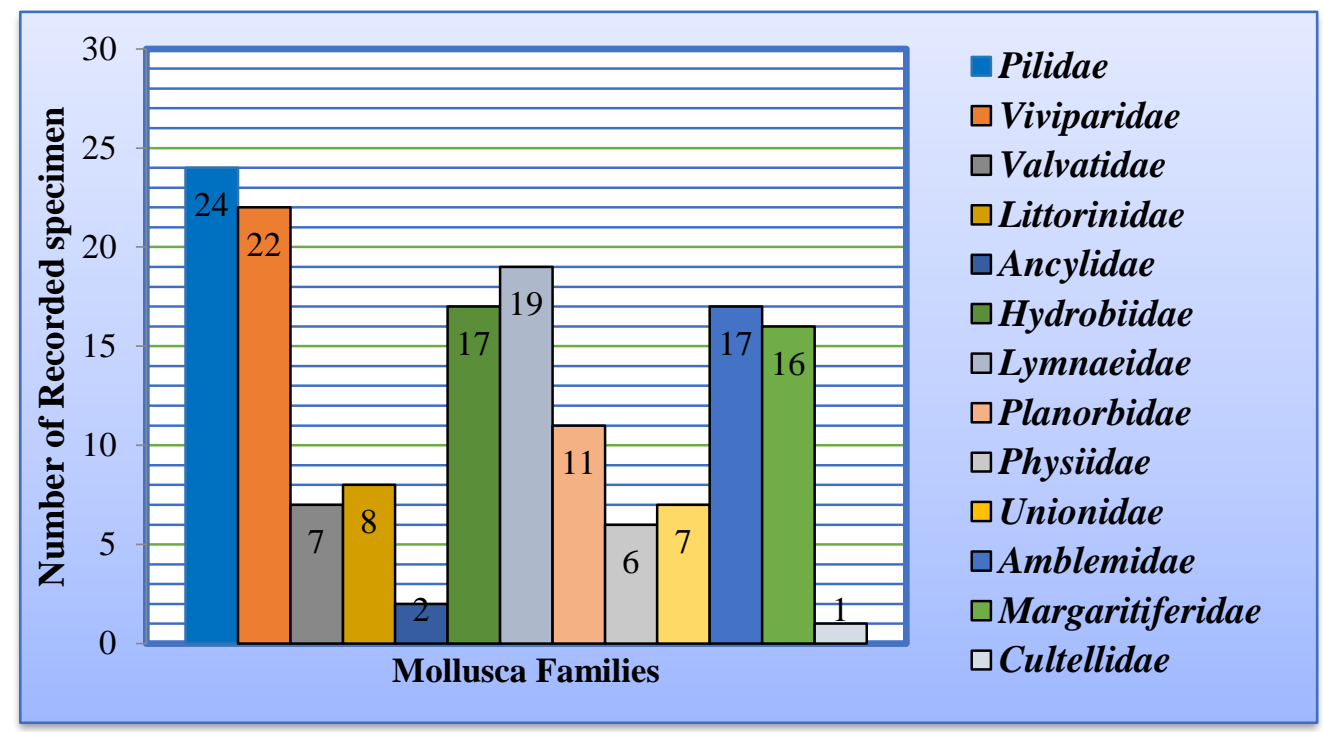

Graph 2: Species wise distribution of Mollusca in Pariyat River at Panagar region of Jabalpur (M.P.). 
Total 157 Molluscan individuals of 13 families were recorded from the study site and represented in (Table 1) and further calculation of diversity indices is tabulated in (Table 2).

Table 2: Calculation of Shannon's Index of general diversity $(\mathrm{H})$ and Simpson's Index of dominance $(\mathrm{C})$ for the Mollusca in Site 1 Pariyat River, Panagar Jabalpur.

\begin{tabular}{|c|c|c|c|c|c|}
\hline Name of Mollusca & $\begin{array}{l}\text { Total no. } \\
\text { of } \\
\text { Mollusca }\end{array}$ & $\mathbf{P i}=(\mathbf{n i} / \mathbf{N})$ & $\operatorname{LogPi}$ & $\begin{array}{l}\text { H=Pi } \quad \text { X } \\
\text { LogPi }\end{array}$ & $\mathbf{C}=(\mathbf{P i})^{2}$ \\
\hline \multicolumn{6}{|l|}{ Class -Gastropoda } \\
\hline Pila sp. & 24 & 0.152866242 & -0.815688411 & -0.124691222 & 0.023368088 \\
\hline Bellamya sp. & 22 & 0.140127389 & -0.853476972 & -0.119595499 & 0.019635685 \\
\hline Valvatapiscinalis & 7 & 0.044585987 & -1.350801612 & -0.060226823 & 0.00198791 \\
\hline Cremnoconchus sp. & 8 & 0.050955414 & -1.292809665 & -0.065875652 & 0.002596454 \\
\hline Ferrissia sp. & 2 & 0.012738854 & -1.894869657 & -0.024138467 & 0.000162278 \\
\hline Potamopyrgus sp. & 17 & 0.108280255 & -0.965450731 & -0.104539251 & 0.011724614 \\
\hline Lymnea sp. & 19 & 0.121019108 & -0.917146051 & -0.110992197 & 0.014645625 \\
\hline Segmentia sp. & 11 & 0.070063694 & -1.154506967 & -0.080889023 & 0.004908921 \\
\hline Physellaacuta & 6 & 0.038216561 & -1.417748402 & -0.054181468 & 0.001460505 \\
\hline \multicolumn{6}{|c|}{ Class: Bivalvia (Two valved Shell) } \\
\hline Lamellidens sp. & 7 & 0.044585987 & -1.350801612 & -0.060226823 & 0.00198791 \\
\hline Parreysia sp. & 17 & 0.108280255 & -0.965450731 & -0.104539251 & 0.011724614 \\
\hline Margaritifera sp. & 16 & 0.101910828 & -0.99177967 & -0.101073087 & 0.010385817 \\
\hline Tanysiphon sp. & 1 & 0.006369427 & -2.195899652 & -0.013986622 & 0.000040569 \\
\hline Grand Total (N) & 157 & - & - & -1.024955387 & 0.10462899 \\
\hline
\end{tabular}

Shannon's Index $(\mathrm{H})=\mathrm{Pi}$ x $\log \mathrm{Pi}=-1.024955387$

Simpson's Index $(\mathrm{C})=(\mathrm{Pi})^{2}=0.10462899$

The Shannon-Wiener index $(\mathrm{H})$ in the present investigation the species diversity of Mollusca in Pariyat river at Panagar region in north of Jabalpur was found to be -1.024955387 at average which indicated high diversity in the study area (Table. 2). It shows both richness and abundance of species in the study area. 
According to the calculation Simpson Index (C) showed the value of species dominance index ranging 0.10462899. The values of Simpson index was increased with decrease of the Shannon diversity which means dominance shows negative correlation with the diversity showing in Graph 3, similar result shown by Al-Nemrawi (2005).

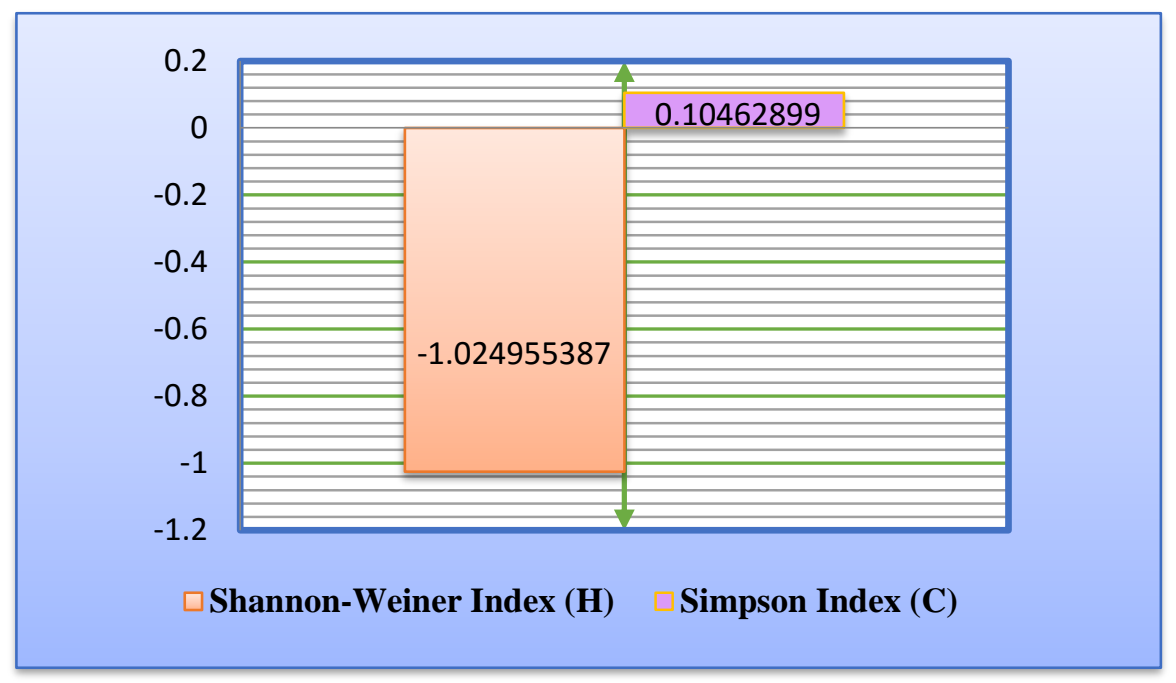

Graph 3: Shannon-Wiener index and Simpson's dominance index of Mollusca in Pariyat river at Panagar region, Jabalpur (M.P.)

It is obviously seen that Mollusca show good species richness but this may have been changed in the environment and industrial or organic pollution site (Al-Saad et al., 2011). Benthic macro invertebrates are susceptible to the local environmental perturbation, which are also effective integrators of the environmental contamination, this means, they were responded to all contaminants in the environment not only those were measured in conventional water or sediment quality monitoring program (Karr, 1986 ).

\section{CONCLUSION}

The findings of this rapid six month study will form baseline information on the catchment of Pariyat River which experiencing gradual changes in land use pattern as well heavy waste discharge. The dairy and industrial activities will increase chemical and organic pollution as well as human disturbance in the study area. Moreover, Pariyat river sludge also affects River Narmada and this will change habitat structure and favorable conditions for aquatic animals.

\section{REFERENCES}

[1] Adoni, A.D., G. Joshi, K. Ghosh, S.K. Chourasia, A.K. Vaishya, M. Yadav and Varma, H.G. Workbook on Limnology. Pratibha Publishers Sagar India, 1985.

[2] Agudo-Padron, A.I. Current knowledge on population studies on five continental mollusks (Mollusca, Gastropoda Bivalvia) of Santa Catarina State (SC, Central Southern Brazil region). Biodiversity Journal, 2(1), 2011, 9-12. 
[3] Al-Nemraw, R. A study of biodiversity of zooplankton and benthic macroinvertebrate in Tigris and Euphrates River in middle Iraq," Ph.D. Thesis, Science college, University of Baghdad, Iraq, 2005.

[4] Al-Saad, H.T., W.A. Farid and Al-Adhub, A.Y. Distribution and seasonal variations of nalkanes in some species of molluscs from Shatt Al-Arab River, Mesopot. J. Mar. Sci., 26(2), 2011, 182- 196.

[5] Begum and Narayan J. Animal diversity of four lentic water bodies in and around Davangare city, Karnataka J. Aqua. Bio. 21(2), 2006. 13-18.

[6] Kalyoncu, H.M. Species composition of mollusca in the Aksu river system (Turkey) in relation to water quality. Fresenius Environmental Bulletin, 18(8), 2009, 1446-1451.

[7] Karr, J.R. Biological Monitoring and Assessment in the Solution of Environmental Problems, Environmental Management, 1986.

[8] Mangurran, A. Ecological Diversity and Its Measurement, Great Britain, 1988.

[9] Shannon, C.E., A mathematical theory of communication. Bell system Technical Journal, 27: 1948, 379-423 and 623-656.

[10] Simpson, E. H. Measurement of diversity. Nature, 163: 688, 1949.

[11] Sklar, F.H. Seasonality and community structure of the Backs swamp invertebrates in Alonisiana Tupelo wetlands, Wetland J., 5: 69-86, 1985.

[12] Sodhi, N.S. Tropical biodiversity loss and people- A brief review. Basic and Applied Ecology. 9: 93-99, 2008.

[13] Strong, E.E., O, Gargominy, W.F. Ponder and Bouchet, P. Global diversity of gastropods (Gastropoda; Mollusca) in freshwater. Hydrobiologia 595: 149-166, 2008.

[14] SubbaRao, N.V. Freshwater Molluscas of India. In; Rao K.S. (ed.). Recent Advances in Freshwater Biology, New Delhi. (2nded.). Anmol publication. 2: 187-202,1993.

[15] SubbaRao, N.V. Handbook of freshwater Molluscs of India. Zoological Survey of India, Culcutta, 1989.

[16] Tonapi, G.T. Fresh water animal of India an ecological approach. Oxford and IBH Publishing Co. New Delhi, 1980.

[17] Wetzel, G. Limnology Lake and River Ecosystems. (3rded.). academic press. U.S.A., 2001. 